\title{
FANCD2 wt Allele
}

National Cancer Institute

\section{Source}

National Cancer Institute. FANCD2 wt Allele. NCI Thesaurus. Code C86550.

Human FANCD2 wild-type allele is located in the vicinity of 3p26 and is approximately 76 $\mathrm{kb}$ in length. This allele, which encodes Fanconi anemia group D2 protein, plays a role in the mediation of homolog pairing in meiosis, cell cycle checkpoint regulation and the modulation of DNA repair. Mutation of the gene is associated with Fanconi anemia. 